\title{
RELASI AGAMA DAN NEGARA UNTUK PEMBANGUNAN INDONESIA DALAM KONTEK GOOD GOVERNANCE
}

\author{
Oleh: \\ Wisri $^{1} \&$ Moh. Asra ${ }^{2}$ \\ IAI Ibrahimy Situbondo \\ wisri1976@gmail.com \& mohammadasra64@gmail.com
}

\begin{abstract}
:
The concept of government with the authority of God is not in direct contrast to the concept of theocracy whose character is essentially the direct rule of God. God is God, and man is His servant. But one thing to keep in mind that God does not regulate directly, preferably, the power of God delegated to His Messenger, Muhammad duty to spread the new religion and sharia, which all comes from God. Therefore, the Islamic system of government with the law of God as the primary source of authority, can not be categorized as a form of theocratic government directly under the administration.

In simple terms the State is the organization in the region that has the highest legal authority and obeyed by his people. Pancasila as the basic philosophy of the state, the state ideology. Pancasila is used as the basis for regulating the conduct of the state. Therefore, efforts to achieve good governance (good governance) is a good faith which has always been a political agenda in every leadership. Indonesia periodization is one country that is rather difficult to be separated from the cultural practices of corruption that has taken hold in the recesses of government. Even today has a resistance to fight against corruption and fighting corruption. A special team has been formed, but corruption is unstoppable with all the tricks. Therefore, routine effort required in order to create good governance and governance fun.

The biggest problem facing the country appears logical is corrupt actions by officials of the ruling, then with all the problems we are required to continue to reflect, think and do a major breakthrough, and the results of Indonesia is really clean and nice. For it must develop the Indonesian development directed to, First: implications for the development of infrastructure repair roads, bridges and other facilities that support the advancement of Indonesia. Second: Development of
\end{abstract}

\footnotetext{
1 Dosen Tetap Fakultas Dakwah IAI Ibrahimy Sukorejo Situbondo

2 Dosen Tetap Fakultas Syariah IAI Ibrahimy Sukorejo Situbondo
} 
super-structure, which includes the eradication of corruption, the termination of foreign intervention in Indonesia.

In addition, there are various issues that need to be done to address some of the approaches, namely First: Approach the structure, by promoting equality in the distribution of levels, for example, without distinction of religion, ethnicity and other Rasserta that could harm Indonesia. Second: the socio-cultural approach, in this case sebaikya offered before society is awareness of human values in religious life, state and nation. With a sense of optimism and spirit of nationalism that Indonesia would become dignified because the concept of Good Governance can be applied correctly by a layer of the Indonesian nation.

\section{Key words: Riligion, State and Good Govermance}

\section{A. Pendahuluan}

Diskursus menyangkut relasi atau hubungan antara agama dan negara sering menjadi topik utama dalam banyak event ilmiah baik lokal, nasionan bahkan internasional. Perbincangan soal ini sering mengemuka sejak kurun-kurun awal kelahiran Islam itu sendiri hingga sekarang. Hal ini dapat dimaklumi lantarang al-Qur'an dan al- Hadits sebagai sumber primer ajaran Islam tidak pernah berbicara secara detail ( juz'iy) dan terperinci (tafshiliy) menyangkut relasi agama dan negara. Sebaliknya teks wahyu banyak mengungkapkan soal hubungan negara dan agama secara global (ijmali) dan garis besarnnya saja (kulli). Karenanya wajar jika persoalan ini selalu up to date diperbincangka oleh banyak kalangan, utamtanya di abad sekarang ini yang ditandai dengan perkembangan ilmu ketatanegaraan yang cukup pesat.

Dari sudut kerjasama, pengalaman politik umat Islam dilalui dengan penuh keragaman pola dan bentuk pemerintahan sesuai tingkat perkembangan masyarakat dan ilmu ketatanegaraan. Pada masa Rasulullah masih hidup, relasi agama dan negara belum mengemuka lantaran beliau sendiri yang meng-handle persoalan seluk beluk negara dengan bimbingan wahyu.

Hubungan negara dan agama seakan tak pernah habis diwacanakan sepanjang sejarah pemikiran agama itu sendiri. Ini bisa dimaklumi lantaran persentuhan keduanya tidak dapat dielakkan, bahkan sejak awal kemunculan Islam 15 abad silam. Fase Makkah yang di jalani nabi selama 13 tahun belum banyak mengupas persoalan relasi agama dan negara karena pada masa ini stressing ajaran agama lebih fokus pada konsolidasi bidang aqidah dan dasar-dasar ajaran agama lainnya. Baru pada fasa

50 $\mid$ JURNAL LISAN AL-HAL 
Madinah wacana hubungan agama dan negara mulai menyeruak kepermukaan, kususnya ketika selama sepuluh tahun di kota ini komunitas Islam sering bersinggungan dengan komunitas lain, seperti Yahudi dan Nasrani. ${ }^{3}$

Diskursus negara-agama kian memiliki mumentumnya pasca runtuhnya kerajaan Islam Turki Uthmani pada abad ke-19. Sejak abad inilah wacana negara bangsa yang multi-etnik, multi-ras,multi-kultural, dan kalangan. Tak pelak lagi, banyak teori yang dimunculkan para pakar menyangkut hubungan negara dan agama. Beberapa teori tersebut diantaranya adalah teori negara agama, teori negara sekular, dan teori simbiotik yang dinilai cukup relevan di terapkan dalam konteks negara bangsa.

Sedangkan ideologi politik adalah kumpulan nilai, norma dan kepercayaan yang dimiliki oleh seseorang atau kelompok orang, atas dasar mana dia menentukan tingkah laku politiknya secara tepat. Nilai dan ide itu merupakan satu sistem yang berkaitan antara satu dengan yang lain. Dasar ideologi politik adalah keyakinan akan adanya suatu pola atau tertib sosial politik yang adeal. Contoh ideolgi politik ini adalah demokrasi, leninisme, marsisme, leberalisme, facisme dan sebagainya. ${ }^{4}$

Pendapat Zainuddin Maliki yang membedakan antara paradigama dengan ideologi, yaitu: bahwa ideologi biasanya mengacu pada kepada sistem keyakinan yang menjadi dasar tindakan sekelompok orang. Oleh karena itu ideologi mendorong dan mendasari tindakan seseorang, sehingga sangat dibutuhkan untuk menghadapi realitas kehidupan. Ideologi menurutnya memberikan satu tatanan nilai yang komprehensif sehingga menjadikan kehidupan ini lebih bermakna.....Ideologi juga cenderung merepresentasikan simbul pandangan dunia yang melegitimasi kepentingan ekonomi politik elit. 5 50.

${ }^{3}$ Abu Yasid, Fiqh Politik, Perspektif Islam ( Situbondo: Ibrahimy Press, 2009), hlm.

${ }^{4}$ Menurut Meriam, jika mengacu pada pandangan ini maka dalam sistem politik sesungguhnya ada keterkaitan komponen struktur dan fungsi proses politik, sehingga ketotalitasan unit terjaga eksistensinya agar tidak menyimpang. Sebuah negara bisa disebut kurang konsisten dengan sistem politiknya jika ia menerapkannya menjadi rancu dan tidak berkesinambungan. Baca, Meriam Boediardjo, Dasar-Dasar Ilmu Politik, (Jakarta: Gramedia Pustaka, 2000), hlm.33.

5 Zainuddin Maliki, Rekonstruksi Teori Sosial Modern, (Jogjakarta: Gajah Mada University Press, 2012), hlm. 20-29. 


\section{B. Selayang Pandang Tentang Negara}

Istilah Negara diterjemahkan dari kata-kata asing staat (bahasa Belanda dan Jerman), State 6 (bahasa Inggris), etaa (bahasa Prancis). Istilah staat mempunyai sejarah sendiri. Istilah itu mula-mula dipergunakan dalam abad ke - 15 di Eropa Barat. Anggapan umum yang diterima bahwa kata staat (state, etat) itu dialihkan dari kata bahasa latin status atau statum $^{7}$

Menurut etimologi kata status dalam bahasa latin klasik adalah suatu istilah abstrak yang menunjukkan keadaan yang tegak dan tetap atau sesuatuyang memilki sifat-sifat yang tegak dan tetap itu ${ }^{8}$. Secara sederhana Negara ${ }^{9}$ adalah suatu organisasi dalam suatu wilayah yang memiliki kekuasaan tertinggi yang sah dan ditaati oleh rakyatnya. ${ }^{10}$

Menurut Grotius, sebelum ada Negara, kehidupan rakyat pada suku-sukuprimitif, misalnya sangat kacau. ${ }^{11}$ Hal ini disebabkan karena setiap orang bebas untuk melakukan apa saja sesuai dengan kehendaknya. Masyarakat menjadi tidak tertib, karena alas an inilah maka Negara

6 State memiliki banyak arti, diantaranya : Negara, keadaan, kebesaran dan lain-lain. Lihat John M. Echols dan Hasan Shadily, Kamus Inggris Indonesia, (Jakarta: Gramedia, 2008), hlm.553

7 Ni'matul Huda, Ilmu Negara, (Jakarta:Raja Grafindo Persada, 2013), hlm.1

8 Ibid

9 Pandangan Socrates : semua manusia menginginkan kehidupan aman, tenteram dan lepas dari gangguan yang memusbahkan harkat manusia. Kala itu orang-orang mendambakan ketenteraman menuju bukit dan membangun benteng, serta mereka berkumpul disana menjadi kelompok. Kelompok inilah yang oleh Socrates dinamakan polis. Organisasi yang mengatur hubungan antara orang-orang yang ada di dalam polis itu tidak hanya mempersoalkan organisasinya saja, tapi juga tentang kepribadian orangorang disekitarnya. Socrates menganggap polis identik dengan masyarakat dan masyarakat identik dengan Negara. Lihat Abu Daud Busroh, Ilmu Negara, (Jakarta: Bumi Aksara, 2011), hlm.21

10 Meriam Boediardjo, Dasar-Dasar Ilmu Politik, hlm.17.

11 Senada dengan Grotius, Thomas Hobbes seorang filosof Inggris mengklaim bahwa : masyarakat chaos modelnya yang ditandai peperangan terus-menerus antar manusia, tidak sepenuhnya khayalan. Hal ini didasarkan pada sebagaimana ditegaskan oleh Hobbes bahwa masyarakat internasional pada masanya. Waktu itu tidak ada otoritas sentral hegemonik yang mamapu memasukkan sebuah tatanan kepada bangsa-bangsa. Dengan berarti berlaku pada semua waktu, raja, perorangan dan otoritas yang berdaulat yang berada dalam sikap perang. Baca Abdel Wahab el Afendi, Masyarakat Tak Bernegara: Kritik Teori Politik Islam, (Yogyakarta:LKiS:2012), hlm.81

$52 \mid$ JURNAL LISAN AL-HAL 
didirikan, dengan kekuasaan yang mutlak. ${ }^{12}$

Bercermin dari perjalanan demokrasi dan perpolitikan di Indonesia menunjukkan bahwa tradisi politik kekuasaan di Negara kita seakan tidak berprikemanusiaan yang pada akhirnya menyeret ke lembah praktek korupsi. Momentum pemilu bukan hanya sebagai peralihan kekuasaan secara konstitusional tetapi telah dimanfaatkan segelintir elit untuk memperebutkan kekuasaan secara kurang beretika. Kalau kita cermati makna politik ${ }^{13}$ maka yang terlintas dibenak kita adalah kepentingan dan kepentingan, sejalan dengan makna politik tersebut yang ditonjolkan adalah kepentingan. Pada kenyataannya bahwa politik memiliki beragam warna, diantaranya adalah :

Pertama, Politik Kebangsaan atau Kenegaraan Dalam hal ini yang dikedepankan adalah loyalitas kepada NKRI dank redo Pancasila 14 sebagai ideology kenegaraan. Mengedepankan loyalitas kepada NKRI dank redo Pancasila adalah hal yang penting, apabila hal tersebut tidak teruwujud niscaya bangsa ini bisa dipastkan akan terurai atau terpecah

12 Ni'matul Huda, Ilmu Negara......., hlm.39

13 Politik, secara etimologi berasal dari bahasa Yunani-Purba yaitu polis, Polis adalah kota yang dianggap Negara yang terdapat dalam kebudayaan Yunani-Pura, dimana pada waktu itu kota dianggap identik dengan Negara, dengan demikian polis, stadstaat atau the grek citystaat ialah tempat-tempat tinggal bersamadari orang-orang biasa selaku para warganya (citizent) dengan pemerintah yang biasanya terletak di atas bukit dan dikelilingi benteng tembok untuk menjaga keamanan mereka terhadap serangan musuh yang dating dari luar.kemudia dari istilah Polis ini diturunkan dan dihasilkan kata-kata politeia (segala hal ihwal yang menyangkut polis atau Negara), polites (warga kota atau warga Negara), politicos (ahli Negara), politieke techne (kemahiran politik), politieke episteme (ilmu politik) dan kemudian istilah polis diambil oleh orang Romawi dan menh \ghasilkan perkataan "as politica" (pengetahuan tentang Negara atau kemahiran tentang masalah-masalah kenegaraan. Baca : Abu Daud Busroh, Ilmu Negara...... hlm.9

14 Dengan mengamati lima sila Pancasila atau pokok-pokok pikiran dalam UUD 1945, hakekat Pancasila dengan ke-lima silanya yang memuat Ketuhananm Kemanusiaan, Persatuan, Kerakyatan dan Keadilan merupakan prinsip dasar yang menjadi cita-cita serta harapan yang dituju oleh bangsa Indonesiauntuk diwujudkan menjadi kenyataandalam kehidipan pribadi, bermasyarakat, berbangsa dan bernegara. Prinsipprinsip tersebut mengandung tiga masalah pokok dalam kehidpan manusia Indonesia, yaitu bagaiman seharusnya manusia berhubungan dengan Tuhan, dirinya sendiri dan lingkungannya. Nilai-nilai Pancasila itu timbul dari bangsa Indonesia, sebagai hasil pemikiran filsafat bangsa Indonesia. Nilai-nilai Pancasila itu diyakini sebagai filsafat (pandangan hidup) bangsa Indonesia yang baik, benar, adil dan bijaksana dalam memedomani kehidupan bermasyarakat, berbangsa dan bernegara. Lihat Sjechul Hadi Penomo, Relevansi Filsafat Hukum Nasional dan Filsafat Hukum Islam, Suatau Tinjauan Komparati", Akademika Vol.14,No,2 (Maret,2004), hlm.123-124 
belah, pepecahan merupakan hal harus dihindari demi terwujudnya integritas Negara dan perdamaian dunia.

Kedua, politik kerakyatan yang didalamnya selalu ada subtansi untuk selalu melindungi, membentengi ketidak adilan, diskriminatif serta harus menerima aspirasi dari masyarakat tanpa harus membeda-bedakan suku, agama dan ras, oleh karena kekuatan politik yang dinamis dan demokratis harus terwujudkan secara nyata dan bisa dirasakan oleh seluruh lapisan organ-organ (masyarakat dan pemerintah) Negara. Jika yang terjadi senaliknya, maka dapat dipastikan akan muncul nuansa egaliter yang selalu mengedepankan kesamaan antar sesame manusia menjdai sirna dan hanya menjadi cita-cita belaka tanpa ada wujud nyata.

Ketiga, politik etika, selalu mengedepankan moralitas atau keadaban dalam berpolitik ${ }^{15}$ kalau kita menyoroti panggung politik saat ini , tampaknya masih banyak politisi yang seringkali melakukan apologitik, sehingga berimplikasi pada hilangnya moralitas bangsa dan tentunya ini tidak berbanding lurus dengan jargon pesan adab dalam agama, ${ }^{16}$ yakni rahmatan lil a'lamin dalam Islam, ${ }^{17}$ cinta kasih dalam

15 Francis Fukuyama menyebutkan bahwa setiap perubahan merangsang terjadinya guncangan. Guncangan karena adanya distingsi (drajat perbedaan reaksi seseorang terhadap berbagai stimulus atau peristiwa yang berbeda) antara nilai baru dengan nilai lama dalam sebuah masyarakat. Lantas dengan ketidaksiapan mereka akan guncangan politik, ahirnya mereka melakukan pengebirian dan pengesampingan etika dalam jagad perpolitikan, pada kenyataannya etika politik merupakan kristalkisasi dari nalar (logika) politik warga bangsa itu snediri. Ia merupakan muara sintesis dari logika-logika yang berkembang pada ranah publik demi terbangunnya kohesi sosial. Pelanggaran terhadap etika politik dengan sendirinya menandakan matinya nalar kebangsaan dan dapat mengancam integrasi sosial.aristoteles dalam karya besarnya (Magnum Opus), nicomachean etichs (kebijakan dan karakter moral yang memainkan peranan penting dalam mendefinisikan etika) menyebutkan bahwa kebaikan bersama merupakan muara etika politik sebuah Negara. Dan etika yang baik hanya mungkin tercipta dalam Negara yang menyediakan tata aturan yang mengarahkan setiap perilaku warga negaranya demi kebaikan bersama. Dari sini kita bisa mengukur apakah perilaku politik yang berkembang di negeri ini mengarah pada kepentingan bersama (rakya) atau justru mengkristal menjadi kepentingan kelompok atau pribadi. Lihat A. Bakir Ihsan, Etika dan Logika Berpolitik, (Bandung: Rosdakarya, 1999), hlm. 20-21

16 Pendapat Dalai Lama : "The whole purpose of religion is to facilitate love and compassion, patience, tolerance, humility, and forgiveness" (Maksud semua agama adalah untuk memfasilitasi cinta dan kasih sayang, kesopanan toleransi, kemanusiaan dan memaafkan). Dalam narasi sejarah peradaban manusia, wajah agama seringkali menampakkan roman yang tidak ramah. Tidak dapat dipungkiri banyak konflik terjadi karena gesekan dan benturan antar agama. Tidak terhitung pula korban manusia yang tumbal atasnya, jika sudah begini, muncul pertanyaan benrakah agama mengajarkan

54 JURNAL LISAN AL-HAL 
Kristen, anti kekerasan dalam Hindu, kesederhanaan dalam Budha dan lain-lain.

Keempat, Politik Kekuasaan, 18 tampaknya politik hanyalah sebatas alat untuk menggapai kekuasaan semata dan upaya untuk

kebaikan untuk manusia ?, terkhusus agama Islam, Nabi Muhammad SAW mendakwahkan Islam sebagai rahmatan lil a lamin. Islam hadir dalam kehidupan pembawa kedamaian dan kasih saying bagi manusia dan alam.namun jika umat Islam tampil dengan mengangkat pedang, menyimpan bom didakam tas, mencurigai bahkan mengusir tetangga, benarkah ada kedamaina dan kasih sayang di dalamnya ?, barangkali logi pertayanyaaan tersebut tidak bisa diterima oleh sebagian kalangan, akan tetap setiap manusia berhak untuk mengajukan peryanyaan dan boleh jadi tak terhindarkan. Dalam persfektif korban konflik kekerasan yang dipicu masalah keagamanaan, bagaiman psikologi anak yang kehilangan orang tuanya ?.., bagaimana perkembangan anak yang mengalami tindak kekerasn ? Pada kenyataannya manusia adalah pribadi yang befikir dan bertindak berdasarkan referensi pengetahuan dan pengalaman. Apabila seorang anak pada masa kecilnya punya pengalaman buruk berkaitan dengan suatu agama, bagaimanakah ketika dewasa ?.., tidak menutup kemungkinan individu tersebut menyimpan luka mendalam dan cara pandang yang buruk terhadap suatu agama. Demikainlah konflik kekerasan akan menjadi lingkaran setan yang tanpa ujung pangkal, turun - temurun dari generasi ke generasi. Lingkaran setan konflik kekerasan berlatar belakang agama tidak akan terburai putus jika gama masih menjdai realitas langit yang tidak membumi. Maka, perlu kebijakan dan kearifan untuk mengimjplementasikan yatyat dalam kitab suci demi kemaslahatan umat tanpa mengurangi esensi dari keimanan. Lihat Syaiful Arif, Humanisme Gus Dur: Pergumulan Islam dan Kemanusiaan, (Yogyakarta: Ar Ruzz Media, 2013), hlm. 5-6.

17 Islam sebagai agama samawi yang komponen dasarnya adalah akidah dan shari'ah, punya korelasi erat dengan politik dalam arti yang luas, sebagai sumber motivasi masyarakat. Islam berperan penting menumbuhkan sikap dan perilaku sosial politik. Implemetasinya kemudia di atur dalam shari'ah, sebagai katalog lengkap dari perintah dan larangan Allah, pembimbing manusia dan pengatur lalu lintas aspek-aspek kehidupan manusiayang kompleks. Islam dan politik mempunyai titik singgung erat, bila keduanya dipahami sebagai sarana menata kebutuhan hidup manusia secara menyuluruh. Islam tidak hanya dijadikan kedok untuk mencapai kepercayaan dan pengaruh dari masyarakat semata. Politik juga tidak hanya dipahami sekedar sebagai srana menduduki posisi otoritas formal dalam structural kekuasaan. Lihat MA. Sahal Mahfudh, Nuansa Fiqh Sosial (Yogyakarta: LKiS, 2011), 2013

${ }^{18}$ Dalam kancah dunia perpolitikan mulai dari zaman purba sampai saat ini sangat kita sayangkan mengapa yang muncul dan tetap eksis hanyalah politik kekuasaan, dimana politik hanya digunakan sebagai alat (instrument) untuk mencapai kursi jabatan yang empuk, bila kita cermati bersama politik bukanlah sebagai maqasid (perantara) untuk mewujudkan kesejahteraan sosial (social walfare). Sebuah pemandangan yang menyayat hari. Bila politik berkawin-mawin dengan kekuasaan, lantas berkembang biak melahirkan lubang hitam maka yang akan muncul dan lahir adalah tindakan korup yang membuat pejabat bersuka cita di atas penderitaan rakyat. 
mensejahterakan rakyat hanyalah pemanis belaku---jauh panggang dari api---, masyarakat terabaikan kesejahteraannya.

\section{Pancasila sebagai Falsafah Negara}

Pancasila sering dibut sebagai dasar falsafah Negara (filosofische gronslag), ideology Negara (staatidee). Pancasila digunakan sebagai dasar mengatur pemerintahan Negara atau sebagai dasar mengatur penyelenggaraan Negara. ${ }^{19}$ dari sudut sejarah, Pancasila diusulakan senagai dasar Negara pertama-tama diusulkan oleh Ir. Soekarno pada siding Badan Penyelidik Usaha-usaha Persiapan Kemerdekaan Indonesia (BPUPKI) dalam rapatnya mencari filosofische gronslag untuk Indonesia yang merdeka, maka diputuskan Pancasila sebagai dasar negara. 20

Sejak saat itulah Pancasila digunakan sebagai nama dari falsafah Negara dan pandangan hidup bangsa Indonesia, meskipun terdapat beberapa tata urut dan rumusan yang berbeda, sejarah rumusan Pancasila tidak dapat dipisahkan dengan sejarah perjuangan bangsa Indonesia serta tidak dapat pula dipisahkan dari sejarah perumusan UUD 1945. ${ }^{21}$ Pancasila sebagai dasar Negara berarti bahwa setiap tindakan rakyat dan Negara Indonesia harus sesuai dengan Pancasila yang sudah ditetapakan sebagai dasar Negara. ${ }^{22}$

19 Titik Triwulan Tutik, Konstruksi Hukum Tata Negara Indonesia Pasca Amandemen UUD 1945, (Jakarta:Kencana, 2011), hlm.78.

20 Pada ahir masa kolonianisme, muncul perdebatan mengenai dasar Negara (konstitusi), sebagian diantar mereka ada yang menginginkan dasar Negara Indonesia adalah Islam, sementara yang lain menghendaki agar dasar Negara Indonesia adalah nasionalis (sekuler). Perdebatan tentang dasar negar mulai memanas pada bulan-bulan menjelang proklamasi kemerdekaan Indonesia, 17 Agustus 1945. Ditengah perdebatan tentang bentuk Negara, menurut Andree Feillard, berangkat dari hasil urun rembuk dengan ketiga tokoh kenamaan muslim yaitu : Kiai Wahid Hasyim, Kiai Masykurkeduanya dari NU- dan Kahar Muzakkar dai PII, pada tanggal 1 Juni 1945, Soekarno berupaya mengatasi persoalan tersebut dengan mengajukan "lima dasar" atau Pancasila sebagai landasan filosofis Indonesia. Lihat Chafid Wahyudi, NU \& Civil Religion; Melacak Akar Civil Riligion dalam Keagamaan NU, (Yogyakarta: Graha Ilmu, 2013), hlm. 80.

${ }^{21}$ Titik Triwulan, Konstruksi Hukum...., hlm.78.

${ }^{22}$ Kalau Nabi dahulu merupakan pemimpin tunggal dengan otoritas yang berlandaskan ke-Nabi-andan bersumberkan wahyu, serta bertanggung jawab atas segala tindakan kepada Tuhansemata, maka tidaklah demikian posisi khalifahpengganti Nabi, hubungan mereka dengan rakyat atau dengan umatberubah menjadi hubungan antar dua peserta dari suatu kesepakatan atau "kontrak sosial" yang memberikan kepada maasingmasing hakdan kewajiban atas dasar timbal balik, seperti yang tercermin dalam baiat

$56 \mid$ JURNAL LISAN AL-HAL 
Pancasila dipandang sebagai dasar Negara Indonesia karena di dalamnya mengandung asas (lima sila), yaitu :

1. Asas Ketuhanan Yang Maha Esa

2. Asas Perikemanusiaan

3. Asas Kebangsaan

4. Asas Kedaulatan Rakyat

5. Asas Keadilan Sosial

\section{Agama Dan Negara}

Teori negara agama menyatakan bahwa negara dalam kondisi apapun tidak dapat dipisahkan dari agama. Ini sebagaimana secara konseptual, agama juga tidak dapat dipisahkan begitu saja dari selukbeluk politik. Sebab,menurut teori ini, semua upaya pemikiran seorang Muslim tentang moral dan politik bisa dipastikan mempunyai dassardasar keagamaannya. Dengan ungkapan lain, menurut paradigma pemikiran ini, negara merupakan lembaga politik dan agama sekaligus. AlMaududi, misalnya, menyodorkan teori teokrasi dimana pemerintahan sebuah negara di selenggarakan atas dasar kedaulatan Tuhan. ${ }^{23}$

Apa yang di tawarkan Al-Maududi ini sebenarnya berbeda dengan teori negara teokrasi ala eropa tempo dulu. Pada saat itu kelompok pendeta, yakni suatu kelompok masyarakat khusus melakukan dominasi

yang disusul dengan "pidato pengukuhan" kiranya dapat dikatan bahwa para khalifah dan rakyat itu masing-masing terikat oleh kesepakatan dua tingkat. Pada tingkat pertama kedua belah pihak bersepakat hendak tetap dan terus melaksanakan ajaran Islam sebagimana yang diwariskan oleh Nabi. Kemudian tingkat selanjutnya kedua belah pihak bersepakathendak melestarikan dan mempertahankan kehidupan bernegar yang telah dirintis oleh Nabi, dalam hal itu rakyat mempercayakan pengelolaan urusan mereka kepada para khalifah disertai janji kesetiaan. Sebaliknya para khalifah menjamin terus tegaknya Islam dan keamanan jiwa, keluargadan harta benda rakyat, serta bertanggung jawab atas kesejahteraan umum. Lihat Munawir Sjadzali, Islam dan Tata Negara; Ajaran, Sejarah dan Pemikiran, (Jakarta: UI Press, 1993), hlm.31

Dalam kontek ke-Indonesia-an, tentunya yang terjadi adalah "kontrak sosial" antara Presiden dan rakyat, dalam hal ini Presiden dituntut untuk mejaga terus tegaknya Pancasila yang didalamnya terkandung nuansa atau nilai-nilailslami, sehingga terwujudlah keamanan jiwa, keluarga dan harta benda rakyat, serta muncullah kesejahteraan umum.

23 Abd. Salam, Kata Pengantar buku, Aspects of The Islamic State: Religious Norms and Political, karya Monoucher Paydar, dalam edisi Indonesia, Legitimasi Negara Islam: Problem Otoritas Shari'ah Dan Politik Penguasa (Yogyakarta: Pajar Pustaka Baru, 2003), hlm.x. 
tak terhingga dan menegakkan hukum-hukumnya sendiri atas nama Tuhan. Pada akhirnya, mereka memaksakan keilahian dan ketuhanan mereka sendiri atas rakyat. Sistem pemerintahan semacam ini, menurut Al-Maududi, justru lebih bersifat syaithaniyyah ketimbang ilahiyyah. ${ }^{24}$

Yusuf Al-Qardlawi, pemikir Islam asal Mesir, menegaskan bahwa negara Islam adalah negara madani yang di tegakkan berdasarkan pemilihan, baiat, dan musyawarah. Kepala negara bertanggung jawab dihadapan rakyatnya. Setiap individu masyarakat berhak menasehati penguasa, menyuruhnya berbuat baik dan melarangnya berbuat munkar. Penguasa menurut pandangan Islam terikat oleh ketentuan-ketentuan, nilai-nilai, dan hukum-hukum syariat. Sebaliknya penguasa tidak bisa seenaknya membuat hukum sendiri, berfoya-foya, otoriter, anti kritik, dan lain sebagainya. Setiap pribadi muslim boleh menentang bila disuruh penguasa melakukan sesuatu yang berlawanan dengan syariat. ${ }^{25}$

Dengan demikian, negara Islam sesungguhnya tidak identik dengan negara teokrasi yang selalu mengatasnamakan Tuhan. ${ }^{26}$ Lebih tepatnya negara Islam disebut negara teo-demokrasi yang memadukan unsur ketuhanan dengan demokrasi. Hal ini dapat dimengerti lantaran teks agama sendiri tidak berbicara secara mendetail (tafshili) dan partikular (juz'i) soal seluk-beluk perpolitikan, sehingga cara merumuskannya memerlukan pembahasan dan permusyawaratan ditingkat rakyat maupun penguasa. Mengabaikan permusyawaratan justru bertentangan dengan prinsip-prinsip politik dalam Islam seperti di sebutkan dalam teks agama.

Namun demikian, teori negara Islam yang secara lebih dominan berkembang dimasyarakat bukan sekedar menggabungkan unsur ketuhanan dengan demokratisasi. Sebaliknya, negara Islam lebih dipahami sebagai formalisasi Islam dalam wujud dasar negara dan pemberlakuan syariat Islam secara legal dan formal. Kelahiran teori negara Islam dengan pengertian ini beriringan dengan munculnya gerakan fundamentalisme Islam yang dimotori oleh beberapa tokoh semisal Abul A'la al-Maududi (Pakistan), Hasan Al-banna (Mesir), dan Sayid Qutub (Mesir). Gerakan ini mulanya diproyeksikan untuk merespons modernisasi barat yang eksisnya dinilai telah merambah dunia Islam.

${ }^{24}$ Adian Husaini, Islam Libral, (Jakarta: Gema Insani: 2004), hlm.15.

${ }^{25}$ Ibid., hlm.15.

26 Cara memerintah negara berdasarkan kepercayaan bahwa Tuhan langsung memerintah negara, hukum negara yg berlaku adalah hukum Tuhan, pemerintahan dipegang oleh ulama atau organisasi keagamaan.

58 JURNAL LISAN AL-HAL 
Hasan Hanafi, pemikir Islam dari Mesir, menegaskan bahwa gerakan ini berusaha menegakkan dan merealisasikan syariat Islam serta membangun sistem yang Islami dengan menolak sistem-sistem non-Islam yang berlaku saat ini. Lebih jauh gerakan ini berusaha mendasarkan relitas kehidupan pada dasar Islam mengingat dasar-dasar yang lain dianggap tidak sah. Karena itu, jika ia dipergunakan sebagai dasar maka realitas menjadi rusak seperti yang terjadi selama ini. Gerakan ini meyakini bahwa berbagai masalah yang timbul dewasa ini disebabkan manusia tidak menerapkan ajaran Tuhan dengan sebenar-benarnya. Jika ingin masalah-masalah tersebut bisa diatasi maka satu-satunya cara adalah menerapkan syariat Tuhan meskipun relitas menolaknya. ${ }^{27}$

Gerakan ini, masih menurut Hasan Hanafi, mempunyai kecenderungan membuat analisis persoalan berdasarkan ajaran syariat yang bersifat ideal, bukan pada realitas. Mereka menghendaki realitas mengikuti idealisme ajaran syariat, bukan sebaliknya, yakni syariat mengikuti realitas. Dengan ungkapan lain, dalam kondisi apapun perkembangan realitas harus mengacu secara formal pada ajaran agama. Dari perspektif inilah gerakan ini lalu disebut fundementalisme atau dalam bahasa arabnya, al-ashalah.

Jika dalam teori negara demokrasi modern disebutkan bahwa kekuasaan mutlak berada ditangan manusia, maka dalam teori negara agama sebaliknya, kekuasaan mutlak berada ditangan Allah yang maha mengatur segalanya. Premis seperti itu membawa kita kepada sebuah kesimpulan bahwa warga negara dari sebuah negara Islam adalah warga negara Allah. Hukum-hukumnya adalah hukum-hukum suci karema ia berasal dari Allah dan tidak dibuat dan ditetapkan oleh manusia. Hukum suci seperti itu merupakan hukum yang mutlak dan manusia hanya bisa mematuhinya, sebab Allah lebih mengetahui dari otoritas manapun atas apa yang dibutuhkan oleh hamba-hambanya. ${ }^{28}$

Namun demikian, apa yang bisa digaris bawahi dari ungakapan ini bahwa hukum-hukum dimaksud sebagian besar merupakan pesan-pesan moral dan prinsip serta pemaknaan secara artikulatif. Betapapun Tuhan mempunyai otoritas mutlak tetapi dia banyak mendelegasikan pada manusia dalam persoalan-persoalan politik dan ketatanegaraan. Nomenklatur hukum Islam yang dirumuskan para juris pasca wafatnya

27 Moh. Nurhakim, Islam, Tradisi, dan Reformasi: Pragmatisme Agama Dalam Pemikiran Hasan Hanafi (Malang: Banyumedia Publishing), hlm.149.

28 Monoucher Paydar, dalam edisi Indonesia, Legitimasi Negara Islam: Problem Otoritas Shari'ah Dan Politik Penguasa (Yogyakarta: Pajar Pustaka Baru, 2003), hlm.39. 
nabi menunjukkan peran interpretasi manusia terhadap kitab suci yang banyak berbicara secara global dan universal. Dalam kontek inilah pemutlakan kekuasaan Tuhan seperti tercermin dalam teori agama, memerlukan perincian dan elaborasi lebih jauh sehingga mudah diterima oleh berbagai pihak.

Pada dasarnya, dalam Islam, anatara negara, agama, pemimpin, individu dan pemerintah tidaklah bisa dipisahkan satu sam lain. Berbagai macam aspek kehidupan manusia, baik dibidang sosial, politik, religius, dan ekonomi tidak bisa dipisahkan begitu saja. Doktrin dan ajaran-ajaran Islam melingkupi dan mendominasi seluruh kehidupan tiap muslim. Ia membentuk sikap, kepercayaan, tingkah laku, dan secara pasti menjadi sebuah way of life (jalan kehidupan) bagi para pengikutnya. Dengan demikian, bukan merupakan sebuah kekeliruan jika seseorang mengklaim bahwa semangat dari keyakinan yang kuat menampakkan dirinya dalam setiap aspek kehidupan seorang muslim. Islam merupakan sebuah doktrin politik religius yang didasarkan pada persaudaraan universal. Negara ideal Islam adalah komunitas iman atau ummah, tanpa memandang ras atau pertimbangan geografis. ${ }^{29}$

Tujuan tertinggi Islam adalah keselamatan dan kesempurnaan diri manusia. Rule of conduct (peraturan tingkah laku) bagi setiap individu dapatlah ditemukan dalam syariat, seperangkat aturan yang diturunkan kepada Nabi Muhammad SAW melalui malaikat Jibril, walaupun pada kenyataannya hukum Islam itu merupakan kumpulan dari interpretasi manusia. Setiap muslim dituntut untuk melaksanakan hukum-hukum Tuhan yang terdapat dalam syari'at. Keseluruhan rule of conduct terangkum dalam ungkapan al-Amr bi al-ma'ruf wa al-Nahy 'an almungkar. Syariat-lah yang menunjukkan kepada kaum muslim mana yang baik dan mana yang mungkar. ${ }^{30}$

Pertanyaan yang muncul adalah bagaimana kaum muslim dapat menyingkap hukum-hukum tersebut. Pada prinsipnya, hukum-hukum Tuhan merupakan perwujudan kehendak-Nya demi keselamatan manusia dan kesempurnaannya didunia dan akhirat. Karena itu ketaatan penuh manusia terhadap hukum sangatlah ditekankan. Hal itu disebabkan oleh pandangan bahwa istilah Islam juga berarti penyerahan dan kepatuhan terhadap kehendak Allah, dimana hal tersebut merefleksikan sifat serta

29 Ibid., hlm.41.

30 Ibid., hlm.42.

$60 \mid$ JURNAL LISAN AL-HAL 
hubungan antara Tuhan dan manusia. ${ }^{31}$

Jika syari'at (masih menurut Yasid) diturunkan oleh Allah kepada manusia yang berkewajiban untuk menjalankan perintah tuhan, hal itu menandakan bahwa ada sebuah perjanjian antara Allah dan komunitas muslim. Dengan ungkapan lain bahwa Allah mengkomunikasikan hokum suci kepada hamba-Nya. Hal itu menimbulkan adanya konsep" perjanjian" antara dirinya sebagai "penguasa" dan hambanya sebagai "yang dikuasai". Tapi dengan perjanjian ini sama sekali bukan berarti posisi antara keduanya adalah sejajar. Hokum suci itu bersifat perintah dari yang kuat kepada yang lemah. Hamba menerima perintah untuk menjalankan hukum-Nya dan berhak mendapatkan hukuman jika mereka terbukti tidak melaksanakan kewajiban mereka. Sedangkan Allah tetap bebas dan tetap maha tinggi. Karenanya, sangat jelas bahwa meskipun Allah dan umat Islam merupakan dua pihak yang berada dalam perjanjian ini, kemungkinan terjadinya sebuah kontrak secara penuh adalah mustahil, walaupun terdapat banyak bukti yang mengindikasikan kemungkinan terjadinya kontrak penuh semacam itu dalam level yang lebih rendah, antara penguasa dan umat Islam. ${ }^{32}$

\section{Islam Dan Politik}

Selama periode awal Islam, konsep tentang Negara, sebagaimana yang kita pahami, tidaklah di kenal dalam kehidupan kaum muslimin meskipun istilah"otoritas yang terorganisir" banyak disebutkan dalam alQur'an pada beberapa kesempatan. Para juris Islam (fuqoha') dan filosof politik kemudian mengembangkan teori pemerintahan dalam perspektif Islam. Mereka meyakini atas kemampuan Negara Islam dan nilai-nilai ultimate-nya untuk mewujudkan kesejahteraan manusia. Mereka juga percaya bahwa kesempurnaan manusia tergantung akan kemampuannya bersosialisasi dengan manusia lainnya.

Al-Farabi dalam hal ini, sebagaimana dikutip Manouchehr Paydar, menandaskan bahwa secara fitrah seseorang tidaklah bisa memenuhi segala kebutuhan tanpa bantuan orang lain. Jika seseorang berkeinginan mencapai kesempurnaan fitrahnya ia harus bermasyarakat dan bekerjasama dengan saudara-saudaranya yang lain. ${ }^{33}$ 55.

${ }^{31}$ Abu Yazid, Fiqh Politik, Perspektif Islam (Situbondo: Ibrahimy Press, 2009), hlm.

32 Ibid., hlm.56.

33 Monoucher Paydar, dalam edisi Indonesia, Legitimasi Negara Islam: Problem Otoritas Shari'ah Dan Politik Penguasa (Yogyakarta: Pajar Pustaka Baru, 2003), hlm. 44. 
Nabi Muhammad sebagai seorang utusan, diberikan kewenangan untuk mewakili Allah SWT dalam menyampaikan pesan-pesan risalahnya di dunia ini. Tetapi otoritas final tetap berada di tangan Tuhan, pencipta sekalian alam. Allah tetap mempunyai otoritas tertinggi atas sesuatu yang berkenaan dengan kehidupan manusia baik didunia maupun di akhirat. Dialah yang membekali hamba-Nya dengan otoritas. Dialah yang memberi dan mencabut kekuasaan meskipun kekuasaan itu dijalankan oleh umat Islam sendiri.

Kehadiran Nabi Muhammad sebagai pemimpin spiritual sekaligus mengendalikan otoritas politik selama mengemban risalah kenabian, dapat dijadikan napak tilas bagaimana seharusnya negara-agama dibangun tanpa memunculkan ketegangan dengan komunitas sekitar. Kedatangannya membawa risalah Islam tampaknya bukan menjadi suatu ancaman bagi struktur sosial yang berlaku pada waktu itu. Islam hanya mengalami sedikit reaksi atau penentangan dari masyarakat arab dan tidaklah berlangsung lama. Sikap tegas Nabi Muhammad dalam menerangi paganisme (tidak beragama) tingkah lakupenentangan pada masyarakat Makkah. Penentangan Muhammad terhadap sebagian tradisi yang telah mapan dan ajakannya pada sebuah doktrin baru menimbulkan beberapa implikasi pada masyarakat Arab. Pertama, mereka harus meninggalkan agama mereka dan menerima sebuah aturan tingkah laku yang baru (Islam). Kedua, mereka ikut serta dalam sebuah komunitas yang menggauli batas-batas kesukuan. ${ }^{34}$

Kurangnya dukungan dari masyarakat Arab dan pertentangan yang diterimanya secara terus-menerus meyakinkan Nabi Muhammad untuk menyebarkan agama ditempat lain. Usaha awalnya untuk mendapatkan pengikut agamanya diantara masyarakat Tha'if menemui kegagalan. Muhammad tidak menemukan lahan subur hingga ia memperoleh dukungan dari masyarakat Madinah, sebuah kota berjarak 280 mil sebelah uatara Makkah. Akibat perasaan jenuh terjadinya konflik internal serta pertumpahan darah, masyarakat Madinah terus mencari pihak luar yang netral untuk menghentikan permusuhan serta menjamin terwujudnya perdamaian dan keamanan diantara mereka. Karena alasan seperti itulah, kurang lebih 75 orang Madinah mengadakan kesepakatan di al-Aqabah untuk menjadikan Muhammad sebagai saudara mereka sendiri. Peristiwa ini membuka jalan baru bagi terjadinya hijrah. Bantuan serta dukungan yang di janjikan oleh masyarakat Madinah di al-Aqabah memunculkan era

${ }^{34}$ Yasid, Fiqh Politik ..., hlm.58

$62 \mid$ JURNAL LISAN AL-HAL 
baru bagi sejarah Islam. Kaum muslim yang masih mu'allaf dan yang mendapatkan siksaan secara terus menerus dari masyarakat Makkah akhirnya menemukan tempat aman. Hijrahnya kaum muslimin mulai terjadi pada tahun $622 \mathrm{M}$ yang diakhiri dengan kedatangan nabi dan sahabat-sahabat terdekatnya di wilayah Quba pada tanggal 24 September $622 \mathrm{M}^{35}$

Mulai saat itulah, doktrin yang masih baru dan mengalami kegagalan di Makkah mulai mengalami perkembangan. Nabi Muhammad semakin lama semakin menjadi orang yang terkemuka dan berpengaruh. Satu demi satu rintangan yang dihadapi dapat diatasi. Ke-lompok posisi, baik yang bergabung ataupun tidak, terpaksa harus membuang rasa permusuhan mereka. Ketulusan Nabi Muhammad dan kejeniusannya dapat mempersatukan sebagaian besar suku-suku yang bertikai. Beliau kemudian diangkat oleh mereka sebagai pemimpin spiritual dan syeikh. Selama periode Madinah inilah banyak terjadi peperangan, penyatuan dan keberhasilan maneuver-manuver politik yang dilakukan oleh Nabi Muhammad.

Pada tahun $628 \mathrm{M}$, Nabi Muhammad SAW yang bayangannya tentang Makkah terus bersemayam di pikirannya merasa telah memiliki kekuatan yang cukup untuk menyerang kota Makkah, akan tetapi ia dan pengikutnya menyadari bahwa musuhnya masih terlalu kuat untuk ditaklukkan. Meskipun demikian mereka telah merasa memiliki kekuatan yang cukup untuk mengadakan sebuah perjanjian yang kemudian disebut dengan perjanjian hudaibiyah itu membuktikan keunggulan akan kesadaran untuk berkompromi dan sikap kenegarawanan Nabi Muhammad. Perjanjian hudaibiyah telah memberikan fondasi bagi keberhasilannya dalam menaklukkan Makkah. Isi perjanjian Hudaibiyah itu adalah sebagai berikut; ${ }^{36}$

"Atas nama Allah, inilah beberapa butir perjanjian antara Muhammad, putra Abdullah dan Suhail ibnu Amir sebagai utusan Mekkah".

"Tidak akan ada peperangan selama sepuluh tahun, siapapun memiliki kebebasan untuk bergabung dan mengadakan ikatan dengan Muhammad. Jika orang bergabung dengan Muhammad itu masih muda atau tanpa izin ayahnya atau walinya yang masih hidup, maka ia akan

${ }^{35}$ Ibid., hlm.59. Baca juga Mohammad Sa'id Ramdan al-Buty, Fiqh al-Sirah ( Bairut: Dar al-Fikr, 1993), hlm. 255.

${ }^{36}$ Ibid., hlm.60. Baca juga Mohammad Sa'id Ramdan al-Buty, Fiqh al-Sirah ( Bairut: Dar al-Fikr, 1993) 120 
dikirim kembali pada ayah atau walinya. Tapi siapa saja yang bergabung dengan Quraisy, maka ia tidak akan di perintahkan kembali. Muhammad tidak akan kembali pada tahun ini dan memasuki kota Makkah. Tapi tahun berikutnya ia dan para pengikutnya dapat memasuki Makkah dan tinggal selama tiga hari, serta dapat mengelilingi Ka'bah. Selama masa itu, suku Quraisy akan menarik diri ke sekitar bukit. Ketika Muhammad dan pengikutnya memasuki kota Makkah mereka akan dilucuti senjatanya kecuali pedang-pedang yang disarungkan".37

Perjanjian Hudaibiyah hanya akan bertahan tidak lebih dari dua tahun dan Makkah akhirnya takluk di bawah kekuasaan Muhammad dan para pengikutnya pada Januari $630 \mathrm{M}$. persatuan bangsa arab telah terwujud dan merupakan fase awal dari kejayaan Islam. Nabi Muhammad SAW wafat pada tahun 632, dan meninggalkan sebuah komunitas dan Negara yang teratur, terorganisir dan berkuasa, suatu kekayaan dan prestis yang membuatnya menjadi sebuah faktor dominan di semenanjung Arabia.

Misi Nabi Muhammad untuk memperkenalkan keyakinan baru dan meletakkan fondasi bagi terwujudnya sebuah masyarakat beradab sepenuhnya telah terealisir di tengah-tengah kebebasan suku arab yang tanpa batas. Ia telah berhasil mengajarkan sebuah doktrin yang dapat mengkounter sistem yang berlaku pada saat itu. Masa yang kemudian di kenal dengan masa kenabian atau periode pertama sejarah Islam yang ditandai oleh kepemimpinan spiritual dan politik Nabi Muhammad. Pada masa inilah "Negara Islam" (Islamic State) pertama kali muncul dan sebuah fondasi sistem hukum dan politik yang baru mulai terbangun. ${ }^{38}$

Otoritas dan misi Nabi Muhammad menurut kaum muslim adalah berasal dari Allah dan secara eksplisit disebutkan dalam Al-Qur'an;

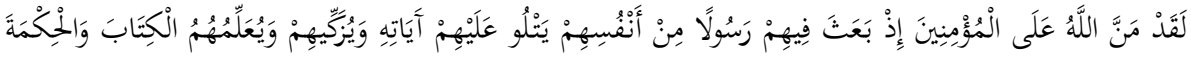

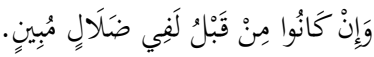

Artinya; Sungguh Allah telah memberi karunia pada orangorang yang beriman ketika Allah mengutus diantara mereka seorang Rasul dari golongan mereka sendiri, yang membacakan kepada mereka ayat-ayat Allah, membersihkan jiwa mereka, dan mengajarkan kepada

${ }^{37}$ Ibid., hlm. 60 .

${ }^{38} \mathrm{Ibid}$. hlm.61.

$64 \mid$ JURNAL LISAN AL-HAL 
mereka kitab dan hikma, sekalipun mereka sebelumnya termasuk dalam kesesatan yang nyata. ${ }^{39}$

Otoritas nabi tersebut mengikat seluruh pengikutnya karena mereka mempercayai bahwa Nabi Muhammad adalah seorang Rasul yang diberi wahyu untuk memimpin dan membimbing mereka. Bahwa dalam kenyataan kaum muslim memandang otoritas yang dimiliki Nabi Muhammad itu berasal dari Allah, serta kenabiannya (nubuwwah) telah ditentukan Allah, maka menjadi suatu kewajiban setiap pengikutnya untuk mengikuti dan mematuhi setiap perintahnya. Dengan demikian, posisinya sebagai nabi memberikan otoritas kepadanya untuk memerintah serta mewajibkan setiap pengikutnya untuk mengikuti setiap ajarannya. Tampak jelas bahwa para sahabat Nabi menyadari betul akan prioritasnya. Abu bakar, Khalifah dan pengganti pertama dalam hal ini mengatakan; "Merupakan sebuah kebenaran bahwa Allah telah mengirim Muhammad sebagai seorang nabi bagi seluruh umat manusia dan sebagai petunjuk bagi para pengikutnya. Karenanya,

setiap hamba Allah bersedia tunduk dan menerima ajarannya mengenai keesaan Allah..." 40

Posisi Nabi Muhammad dan gelar variatif yang disandangkan oleh para sahabat kepadanya atas kewibawaannya telah memberikan pengaruh yang semakin kuat dan menjadikan pengikutnya-pun semakin bertambah banyak. Pada awal masa kenabiannya di Makkah, Nabi Muhammad di juluki sebagai seorang Rasul (a mesenger) bagi kaumnya, suatu istilah yang paling umum digunakan oleh komunitas kesukuan dan kekeluargaan. Tetapi pada akhir periode Makkah, istilah kaum diubah menjadi ummah sebagai konotasi religius yang mengikuti seluruh pengikut yang percaya bahwa ia merupakan utusan Allah. Kemudian ia dijuluki Rasul Allah, yaitu utusan Allah. Ia juga dijuluki gelar lain seperti Nadzir atau member peringatan dan Mudzakkir atau yang memperingatkan. Pada periode awal, Nabi Muhammad tidak menduduki posisi politik apapun. Ia hanya berfungsi sebagai utusan Tuhan dengan ummah (komunitas) sebagai komunitas religiusnya. ${ }^{41}$

Kepindahan (hijrah) Nabi dari Makkah ke Madinah dan perannya sebagai arbitrator bagi seluruh kota, memungkinkan ia untuk menduduki otoritas politik yang sebelumnya tidak pernah ia dapatkan. Konsekwensi

${ }^{39}$ QS. Ali Imran [3] 164

${ }^{40}$ Yasid, Fiqh Politik...... hlm.62.

${ }^{41}$ Ibid., hlm. 63. 
logis dari adanya pemberian kekuasaan seperti itu adalah transformasi ummah dari sebuah komunitas religius murni menjadi sebuah komunitas politik. $^{42}$

Kombinasi otoritas spiritual dan politik yang dimiliki Nabi Muhammad dan transformasi dari komunitas religius menjadi komunitas yang berkuasa dan bertanggung jawab terhadap pelaksanaan segala urusan moral dan sosial, menjadikan Islam sebagai sebuah agama yang doktrin dasarnya lebih menentang adanya pemisahan antara agama dan Negara. Akan tetapi perlu diingat bahwa meski penyatuan bangsa Arab terwujud berkat otoritas Nabi yang tidak tertandingi, namun keberadaannya sebagai nabi dan utusan Allah lebih diperhitungkan ketimbang ia sebagai pemimpin politik. Karena itu, orang patuh padanya bukan karena ia memegang otoritas politik terhadap mereka, melainkan karena ia memiliki mandat langsung dari Tuhan.

Mengenai posisi Nabi Muhammad di Madinah, Ibnu Taimiyah berpendapat sebagai berikut;

Jika dikatakan bahwa ketika Nabi berkuasa di Madinah, ia juga dibantu oleh posisi imamah-nya dalam menegakkan keadilan, maka jawabannya adalah walaupun seandainya ia memiliki posisi sebagai Nabi, para pengikut akan tetap mematuhi dan melaksanakan segala perintahnya serta berperang melawan musuh-musuhnya. Dan selama di dunia masih ada yang percaya kepada Allah dan Nabi-Nya maka mereka akan menjadi pengikut dan pendukung Nabi serta akan senantiasa melaksanakan segala perintahnya dan berjuang melawan musuh-musuhnya. Karena itu, ia tidaklah memanfaatkan para pengikutnya untuk memperoleh kedudukankedudukan yang dapat memperkuat posisi kenabiannya, seperti posisinya sebagai seorang imam, pengambil kebijakan ataupun penguasa. Semua kedudukan itu adalah bersifat inheren dengan kenabiannya. Dengan dukungan para pengikutnya, ia memiliki kekuasaan yang penuh dan mengharuskannya untuk menciptakan seperangkat hukum sreta memimpin jihad, sesuatu yang bukan merupakan keharusan baginya ketika ia semata-mata hanya sebagai penguasa. ${ }^{43}$

Satu faktor kuat dan mengikat seluruh pengikut Muhammad adalah faktor keimanan (faith) yang mampu menyatukan mereka dalam satu komunitas yang terorganisir, al-Qur'an menyebutnya sebagai ummah, dan

42 Ibid., hlm. 63.

43 Ibid., hlm. 64.

66 JURNAL LISAN AL-HAL 
menyebut pengikutnya sebagai mu'minun (orang yang percaya) dan menyebut ideologinya sebagai Islam atau penyerahan diri terhadap Tuhan yang maha esa (Allah). ${ }^{44}$

Muhammad sebagai Nabi dan utusan Tuhan juga sadar akan kewajibannya untuk mengembangkan serta memlihara ajaran Islam dalam tatanan berbangsa dan bernegara. Nabi Muhammad sejak awal masa kenabiannya, ketika harus bersikap sebagai mana layaknya kepala suku, membedakan komunitas ummah dengan komunitas lainnya dengan unsur keimanan. Hal ini sekurang-kurangnya dapat tercermin dalam Piagam Madinah sebagai berikut;

"Dengan nama Allah yang maha pengasih dan maha penyayang. Ini adalah naskah perjanjian dari Muhammad SAW, Nabi dan Utusan Allah, mewakili pihak dari kaum muslimin yang terdiri dari kaum Quraisy dan kaum Yatsrib (Madinah), serta pengikutnya, yaitu mereka yang beriman dan ikut serta berjuang bersama mereka. Mereka adalah sebuah komunitas yang berbeda dengan komunitas lainnya. 45

Implikasi piagam Madinah tersebut adalah terjadinya perkembangan-perkembangan yang dapat diperkirakan sebelumnya, yaitu; pertama, komunitas ini dikaruniai dan memiliki rasa harga diri dan kebajikan sebagai mana dikatakan dalam Al-Qur'an; Dan kami membagi-bagi mereka didunia menjadi beberapa golongan, diantaranya ada dari mereka yang selalu berbuat kebaikan dan sebagian yang lain tidak berbuat demikian.(QS al-A'raf;168). Kedua, Muhammad SAW telah diterima sebagai Rasul dan Nabi yang di utus oleh Allah, dan konsekwensinya, otoritasnya tidak berasal dari para pengikutnya, tetapi dari tuhan. Ketiga, Muhammad SAW telah memanfaatkan otoritas yang dimilikinya untuk menjadi hakim bagi kaum muslimin ketika konflik terjadi diantara mereka. Menurut isi piagam perjanjian, Nabi Muhammad SAW memiliki tanggung jawab yang lebih besar dari pada hanya sebagai pemimpin religius."

"Ummah" atau komunitas kaum mukmin juga menjadi bagian penting dari ideologi politik Islam. Signifikansi dari komunitas ini terletak pada kenyataan bahwa ia terdiri dari kumpulan pengikut Nabi (Jama'ah) tanpa memandang asal usul mereka. Komunitas ini juga mengungguli seluruh batasan-batasan politik dan menjadikan komunitas muslim (Ummah) sebagai oposisi utama bagi konsep modern tentang Negara yang

\footnotetext{
44 Ibid., hlm. 65.

45 Ibid., hlm.64.
} 
diartikan sebagai sebuah kesatuan geo-politik. Implikasi lebih jauh dari komunitas "Ummah", berdasarkan prinsip-prinsip yang telah di sebutkan di atas, adalah munculnya dua entitas yang berbeda dan saling berlawanan yaitu dar Al-Islam (wilayah damai) dan dar Al-harb (wilayah perang). Inilah satu-satunya batasan-batasan politik yang dikenal dalam Islam.

Prinsip dari doktrin politik Islam yang bersifat Ideologis ini berhadapan secara diametral dengan teori modern tentang Negara yang lebih bersifat politis. Menurut doktrin politik Islam ideologis, otoritas tertinggi hanyalah milik Allah. kedaulatanNya meliputi seluruh semesta alam tanpa terkecuali. Tentu saja kehendak-Nya-Lah yang mengatur seluruh dunia dengan ajaran bahwa surga dan bumi, manusia dan jin, benda hidup dan benda mati, semuanya berada dibawah kedaulatan Tuhan. Apabila dalam teori modern tentang Negara (State) kedaulatan mutlak di tangan manusia, maka dalam Negara Islam, kedaulatan mutlak berada di tangan Tuhan Yang Maha Kuasa dan Maha Mengetahui. ${ }^{46}$

Meskipun kedaulatan yang mutlak dan tidak tertandingi berada ditangan Allah dan manusia tidak boleh menggunakan otoritas yang dimilikinya kecuali dibawah rambu-rambu hukum yang telah diwahyukan Allah kepada Nabi-Nya, seorang individu bukan berarti tidak mempunyai kewenangan sama sekali dalam wilayah hukum. Mereka memiliki wewenang yang besar untuk menjalankan kekuasaan dan melakukan perubahan serta menciptakan sebuah hukum berdasarkan tuntutantuntutan keadaan. konsensus publik atau ijma' sebagai sebuah sumber hukum memberikan komunitas muslim sebuah kedaulatan politik dalam kewenangan mereka sendiri. ${ }^{47}$

Penerapan kewenangan itu sangatlah tampak dalam peristiwaperistiwa historis kaum muslim, seperti penetapan Abu Bakar RA sebagai khalifah, penerus nabi. Apa yang dilakukan kaum muslimin ini didasarkan pada kewenangan dan penerapan ijma' semacam itu. Berdasarkan fakta bahwa interpretasi final atas hukum, aplikasi dan penyusunannya adlah menjadi kewenangan manusia, maka banyak wilayah-wilayah otoritas hukum yang dipercayakan pada manusia.

Dengan demikian, syari'ah memberikan wilayah yang luas serta basis yang kuat bagi struktur politik masyarakat Islam. Syari'ah juga memberikan sebuah kerangka pedoman yang fundamental dan berfungsi

46 Ibid., hlm. 66.

${ }^{47}$ Ibid., hlm.66. 
sebagai hukum tata Negara bagi para penguasa (the rules) dan warga Negara (the ruled). Sumber otoritas dan itu dinyatakan dalam sebuah ayat Al-Qur'an bahwa setiap orang beriman mesti taat kepada Allah, Rasul, dan pemimpin yang sedang berkuasa. Menurut makna eksplisit ayat al-Qur'an tersebut bahwa kewenangan (otoritas) dalam urusan komunitas muslim didasarkan pada tiga sumber yang berbeda, yaitu Tuhan, Muhammad, dan yang terakhir perantaraan manusia. ${ }^{48}$

Pengetahuan dan kekuatan absolut Tuhan yang jauh melebihi apa yang dimiliki oleh manusia memposisikan-Nya sebagai pemegang otoritas final. Dia adalah raja dan penguasa yang dapat menjadikan siapa saja yang dikehendaki sebagai pemimpin. Cara penunjukan seseorang sebagai pemimpin juga menjadi otoritas-Nya. Tetapi menurut doktrin politik Islam ideologis, otoritas ini sesungguhnya telah diserahkan-Nya pada manusia.

Meskipun otoritas yang dimiliki oleh nabi Muhammad berasal dari Tuhan, tapi ia memiliki hak untuk dipatuhi secara proporsional karena mematuhinya merupakan sebuah kewajiban yang diperintahkan oleh Allah kepada seluruh manusia. Akan tetapi, otoritas yang dimilikinya bukanlah karena pribadi Muhammad itu sendiri, tetapi karena posisinya sebagai seorang nabi. Karena itu sewaktu ditanya, "engkaulah raja kami?" Nabi Muhammad menjawab, "raja kamu adalah Allah, bukan saya". Bagaimanapun, menurut doktrin politik Islam ideologis human agency juga berhak untuk dipatuhi karena mereka dipilih oleh masyarakat untuk posisi itu dan karenanya mereka punya wewenang untuk menjalankan kekuasaan atas nama mereka (masyarakat).

Hukum Islam pada kenyataannya, membedakan antara kedaulatan tuhan dan kedaulatan manusia. Kedaulatan yang sebenarnya atau kekuasaan mutlak dan otoritas absolut yang tidak dapat dimiliki manusia adalah milik Tuhan semata. Dia merupakan penguasa tertinggi dari setiap makhluk. Dia mengekspresikan kehendak kedaulatannya itu dalam alQur'an dan al-Hadits. Dia memberikan dan mempercayai kedaulatan pada manusia agar mereka dapat melaksanakan segala perintah-Nya dan mewujudkan segala kehendak-Nya. ${ }^{49}$

Sistem yang dibangun oleh Nabi dan kaum mukminin yang hidup bersama beliau di Madinah-jika dilihat dari segi praksis dan diukur dengan variabel-variabel politik di-era modern tidaklah disangsikan lagi bahwa sistem itu adalah sistem politik par-excellence. Dalam waktu yang sama,

48 Ibid., hlm. 68.

49 Ibid., hlm.69. 
juga dapat dikatakan bahwa sistem itu adalah sistem regligius, jika dilihat dari tujuan-tujuannya, motif-motifnya dan fundamental maknawi tempat sistem itu berpijak. ${ }^{50}$

Dengan demikian, suatu sistem dapat menyandang dua karakter itu sekaligus, karena hakikat Islam yang sempurna merangkum urusanurusan materi dan ruhani, dan mengurus perbuatan-perbuatan manusia dalam kehidupannya di dunia dan ahirat dan tidak pernah memisahkan keduanya, namun menyatu secara solid. ${ }^{51}$ Namun demikian ada ummat Islam yang mengkalaim diri sebagai kalangan pembaru dengan terangterangan mereka mengingkari fakta dan menganggap bahwa Islam adalah dakwah agama saja. ${ }^{52}$ Dan menurut mereka bahwa Islam adalah sekadar keyakinan atau hubungan manusia dengan Rabbanya sehingga tidak memiliki hubungan sama sekali denga urusan-urusan yang kita namakan dengan materi dalam kehidupan dunia. Diantara urusan-urusan ini adalah politik dengan mengatakan " Agama adalah satu hal dan politik adalah hal yang lain.” 53 Persoalan kemudian adalah ketika konsep tersebut masuk pada tataran politik praktis, partai-partai politik, apakah relasi agama dan negara dapat diterapkan dalam dunia politik..?

Konstruk pemikiran Islam tentang kekuasaan, relasi agama dan negara hususnya yang menyangkut pengelolaan kekuasaan (religiopolitical power) menurut Zainuddin Maliki telah berkembang sejak abad tengah. Smith membagi pemikiran agama dan politik politik tersebut secara dikotomik dalam religio-political power organik disatu pihak dan skuler dilain pihak. perspektif organik mengklaim perlunya penyatuan agama dan kekuasaan, karena agama menjangkau semua aspek kehidupan manusia, sementara mengklaimperlunya pemisahan antara agama dan kekuasaan dalam rangka menjaga ke-paripurna-an agama. ${ }^{54}$

Dalam Islam banyak khazanah intelektual, artinya bukan hanya perspektif sekularistik dan organik, tapi muncul perspektif lain barcorak diferensiatif. Namun demikian tidak sedikit mereka yang menganut prinsip

50 Eksplorasi lebih mendalam baca; Muhammad Dhiaudin Rais, Al- Nazriyat alSiyasiyat al-Islamiyah, edisi Indonesia, Teori Politik Islam, (Jakarta: Gema Insani Press, 2001), 4.

51 Ibid., hlm.4.

52 Ibid., hlm.4.

53 Ibid., hlm.5.

54Zainuddin Maliki, Sosiologi Politik, Makna Kekuasaan Dan Transformasi Politik, (Yogyakarta: Gajah Mada University Press, 2010), hlm.45.

$70 \quad$ JURNAL LISAN AL-HAL 
organik masih bersedia mempertimbangkan prinsip-prinsip sekulerisme. Demikian pula mereka yang menganut prinsip-prinsip sekulerisme tak tertutup kemungkinan masih terbuka mengambil prinsip-prinsip organik dalam hal tertentu. Oleh karena itu ada negara yang menganut pemisahan antara agama dan negara tapi masih juga melakukan formalisasi ajaran agama tertentu diranah publik, sehingga kemudian muncul istilah "theo demokrasi" dalam hal ini kekuasaan harus memperoleh legitimasi dari "dunia di sana" atau legitimasi theologis, sekaligus juga legitimasi dari dunia " di sini" yaitu dari rakyat secara demokratis. ${ }^{55}$

\section{Upaya Good Governance}

Dalam rangka mewujudkan pemerintah yang bersih (clean governance) adalah I'tikad baik yang selalu menjadi agenda politik di setiap periodesasi kepemimpinan. Indonesia merupakan salah satu Negara yang terbilang sulit untuk mewujudkan ita-citaitu. Pada tahun 1950-an, Bung Hatta pernah berujar bahwa korupsi telah menjadi budaya bangsa. Sekalipun saat itu dekralasi perlawanan terhadap para koruptor telah dikomandangkan dan tm khusus pemberantas korupsi telah dibentuk, namun pada ,asa-masa setelahnya, praktiknya korupsi semakin tak terbendung. 56 yang perlu diperhatikan adalah unsure good govermance terdapat tiga hal, yaitu unsure dibidang ekonomi, politik ${ }^{57}$ dan administerasi.

Pada tahun 1998, siaran pers Transparansi Internasional, sebuah

\section{Ibid., hlm.46}

56 Subhan Setowara dan Soimin, Agama dan Politik Moral, (Malang: Intrans Publishing, 2013), hlm.88

57 Salah satu harapan perbaikan justru dating dari gedung KPK, secara tidak disadari bahwa KPK telah memperkenalkan budaya politik baru yang berpijak pada prinsip tata kelola yang baik dan bersih. Dalam kontek ini cara yang dilakukan oleh KPK adalah memecah konsentrasi individu-individu yang terlibat dalam budaya politik neopatrimonalistik umtuk mempertanggungjawabkan korupsi politik yang telah dilakukannya. Tidak berlebihan jika KPK telah membalikkan kemustahilan menjadi sebuah kemungkinan dan harpan. Pengenalan bdaya politik baru justru dimulai ketika KPK memecah konsentrasi dan memutus pola relasi patron-klien melalui paradigm imparcial law enforcement, pergeseran paradigm politik ini harus di dukung bersama dan harus di sadari oleh siapapun yang hendak memasuki domain politik-kekuasaan. Mudahmudahan langkah KPK memecah konsentarsi neopatrimonalistik ini menandai datangnya era baru budaya politik adi luhung. Jika anda ingin selamat dunia akhirat jangan larut ke dalam system yang ada, tetapi ciptakanlah system politik baru yang akuntabel, bersih, bertanggung jawab dan melayani. Konsekuensinya jika nanti terpilih anda bukan lagi milik parpol dan mengabdi pada parpol, tetapi milk masyarakat dan bangsaini, lihat Masdar Hilmy, "Ihwal Budaya Politik Kita", Kompas (Maret, 2014) 
oragnisasi internasional anti korupsi yang bermarkas di Berlinmelaporkan bahwa Indonesia merupakan Negara terkorup ke-enam di dunia setelah lima Negara gurem, yaitu Kamerun, Paraguay, Honduras, Tanzania dan Nigeria. Tiga tahun kemudia (2001) transparansi internasional justru memasukkan Indonesia sebagai Negara terkorup ke-empat. Pada tahun 2002 hasil survey Political and Economic Risk Sonsultancy yang bermarkas di Hongkong menempatkan Indonesia sebagai Negara terkorup di Asia. Survey Nasional Korupsi yang dilakukan Partneship for Govenance Reform bahkan melaporkan bahwa hamper setengah dari pejabat pemerintah (48\%) diperkirakan menerima pembayaran tidak resmi. ${ }^{58}$

Sejumlah data di atas menunjukkan bahwa kualitas clean Governance Indonesia berada pada titik yang amat rawan. Sulitnya penanganan terhadap korupsi ternyata telah menjdai masalah krusial dalam dunia internasinal. Banyak kepala Negara yang merasa risau dalam menjalankan kepemimpinannya hanya karena persoalan korupsi.

Pergantian pimpinan biasa menjadi momentum bagi setiap bangsa untuk mewujudkan pemerintahan yang bersih dari segala bentuk penyalahgunaan wewenag (abuse of power), setelah dibentuknya Komisi Pemberantasan Korupsi (KPK) kita tentunya berharap agar Negara bisa lebih mampu menjalankan system chek anda balance dan mekanisme control yang efektifterhadap kekuasaan. Namun, upaya mewujudkan clean goverbance tidak akan menjadi kenyataan jika tidak ada kesadaran kolektif dari masyarakat bahwa korupsi adalah musuh bersama (common enemy), solusi pemecahannya tidak bisa diserahkan sepenuhnya pada KPK. Seluruh elemen bangsa ini perlu meneriakkan perlawanan terhadap korupsi.

Ada beberapa faktor yang menyebabkan terjadinya korupsi, setidaknya factor yang menghambat pada terwujudnya clean governance dan rumitnya pemberantasan korupsi. Pertama kesalahan dalam memilih orang-orang yang akan masuk dalam lingkaran birokrasi serta posisi kunci kekuasaan. Kedua miskinnya moralitas dan dangkalnya pada pemahaman ajaran Agama. Ketiga lemahnya rasa cinta pada Negara.

Melihat beberapa kenyataan yang terjadi di negeri ini, seharusnya setiap momentum politik tidak hanya dijadikan sebagai arena untuk mengejar kekuasaan, akan tetapi harus dimaknai sebagai wadah umtuk memilih pemimpin yang berkualitas. Dengan demikian, pemimpin Negara ini harus menyiapkan beberapa jurus ampuh supaya bsa menghadirkan

58 Ibid

$72 \mid$ JURNAL LISAN AL-HAL 
pemerintahan yang bersih dan ini merupakan amanah dari rakyat yang harus dijalankan dan dilaksanakan dengan sebaik-baiknya diatas kepentingan pribadi dan golongan.

Sedangkan nilai-nilai normative anti korupsi dalam Islam bisa dilihat dari keharusan pejabat public yang diangkat untuk memiliki sifat jujur (sidq) ${ }^{59}$ dan akuntabe (amanah) 60

\section{Kesimpulan}

${ }^{59}$ Sifat wajib yang pertama bagi Rasul adalah Jujur, yakni berkata benar dalam semua ucapannya. Aksioma yang menunjukkan wajibnya sifat jujur bagi para Rasul ialah apabila mereka berdusta dalam perkara yang nereka sampaikan kepada makhluk, maka berita dari Allah juga dusta. Padahal Allah telah membenarkan pengakuan mereka sebagi utusan dengan menampakkan mukjizat pada mereka. Mukjizat itu sebagiman firman Allahdalam hadist Qudsi "Benar hamba-Ku, dalam setiap hal yang ia sampaikan dari-Ku". Penjelasan aksioma tersebut ialah : Rasul ketika mendatangi kaumnya dan berkata kepada mereka: "Aku adalah seorang Rasul, Allah telah mengutusku untuk kalian", lalu mereka berkata: "Apa bukti ke-Rasul-anmu ?". Dia menjawab: "berpindahnya gunung ini dari tempat asalnya". Ketika kaumnya berkata: "Buktikan ucapan engkau saat demikian...". Kemudian tatkala waktu yang ditentukan telah tiba, Allah memindahkan gunung tersebut dari tempat semula, guna membenarkan pengakuan Rasul tadi, maka dipindahnya gunung tersbut oleh Allah,sebagimana firmannya: "Benar hamba-Ku, dalam setiap perkara yang ia sampaikan dari-Ku." Seandainya Rasul itu berdusta, maka berita dari Allah juga dusta, sedangkan dusta bagi Allah adalah muhal. Dengan demikian menjadi batal lah apa yang mendatangkan pada sesuatu yang muhal tersebut, dalam kontek ini adalah dustanya seorang Rasul dan menjadi tetaplah kebalikannya (jujur), inilah yang dicari. Apabila telah tetap bahwa Rasul memiliki sifat jujur maka mustahil bagi Rasul sifat dusta. Lihat Shaikh Ahmad al Nahrawi, al Durru al Farid, dicetak bersama Fathu al Majid, (Surabaya:al Hidayah, $\mathrm{tt}$ ), hlm.41-42

60 Sifat wajib yang ke-dua adalah akuntabel, artinya mereka terpelihara dari melakukan perbuatanyang terlarang atau makruh, baik lahir ataupun batin, ketika masih kecil ataupun sudah dewasa. Aksioma yang menunjukkan tetapnya sifat "amanah" bagi para Rasul ialah apabila para Rasul itu berkhianat dengan melakukan perbuatan terlarang atau makruh, berarti kita juga diperintahkan berbuat seperti yang mereka lakukan, karena Allah memerintahkan kita untuk mengikuti Rasul. Tidak dapat dibenarkan bahwa kita diperintah melakukan sesuatu yang haram dan makruh, sebab Allah tidak memerintahkan perbuatan keji. Maka pastilah Rasul tidak melakukan sesuatu kecuali ketaatan, adakalanya berupa wajib atau sunnah. Perbuatan mereka berkisar antara wajib dan sunnah dan katagori mubah tidak termasuk perbuatan mereka, sebab mereka melakukan perkara yang mubah itu dalam rangka menunjukkan kebolehanperkara tersebut atau untuk keperluan tashri' (menunjukkan hukumnya). Perbuatan yang dilakukan Nabi itu adakalanya wajib adakalanya sunnah. Bila telah tetap bahwa Rasul memiliki sifat amanah (akuntabel) maka mustahil bagi mereka sifat hiyanat (berkhianat) dengan melakukan perbuatan haram atau makruh. Lihat Shaikh Ahmad al Nahrawi, al Durru al Farid, dicetak bersama Fathu al Majid, (Surabaya:al Hidayah, tt), hlm.42-43. 
Gambaran komprehensif tentang sifat dasar, fungsi dan tujuantujuan sistem politik Islam dapat ditemukan dalam kitab suci Al-Qur'an yang merupakan sumber hukum pertama dan pedoman hidup kaum muslim. Kesimpulan awal yang mungkin dapat ditarik adalah bahwa karena di Arab tidak ada organisasi politik yang sistematik dan berlakunya sistem kesukuan yang tidak terstruktur, istilah dan konsep tentang negara (al-daulah) tidaklah dikenal pada waktu itu dan karenanya tidak pernah disinggung baik oleh Nabi Muhammad maupun Al-Qur'an. Meskipun secara eksplisit istilah al-daulah tidaklah ditemukan, namun dalam AlQur'an terdapat ayat-ayat yang mengindikasikan bahwa Allah juga memberikan konsep-konsep umum tentang pemerintah negara dan. Istilah "otoritas terorganisir" (organized authority) yang digunakan dalam Al-Qur'an mungkin bisa dijadikan contoh untuk mendukung pernyataan tersebut. Akan tetapi, otoritas terorganisir tersebut merupakan milik dari Tuhan Yang Maha Agung yang kekuasaan-Nya meliputi seluruh alam raya tanpa terkecuali.

Konsep pemerintahan dengan otoritas Tuhan secara tidak langsung adalah berbeda dengan konsep teokrasi yang karakter dasarnya adalah pemerintahan langsung dari Tuhan. Allah adalah Tuhan sedangkan Manusia adalah hamba-Nya. Tetapi suatu hal yang harus diingat bahwa Allah tidaklah memerintah secara langsung, sebaiknya, kekuasaan Tuhan didelegasikan kepada Utusan-Nya, Muhammad SAW yang bertugas untuk menyebarkan keyakinan baru dan syari'ah yang kesemuanya berasal dari Tuhan. Karenanya, sistem pemerintahan Islam dengan hukum-hukum yang berasal dari Tuhan sebagai sumber otoritas utamanya, tidaklah bisa dikategorikan sebagai sebuah bentuk pemerintahan teokratis yang langsung berada dibawah pemerintahan.

Secara sederhana Negara adalah suatu organisasi dalam suatu wilayah yang memiliki kekuasaan tertinggi yang sah dan ditaati oleh rakyatnya. Pancasila sebagai dasar falsafah Negara, ideology Negara. Pancasila digunakan sebagai dasar untuk mengatur penyelenggaraan Negara. Oleh karena itu upaya untuk mewujudkan pemerintah yang bersih (good governance) adalah merupakan I'tikad baik yang selalu menjadi agenda politik di setiap periodesasi kepemimpinan.indonesia merupakan salah satu Negara yang terbilang sulit lepas dari praktik budaya korupsi yang telah mengakar di relung-relung tata kelola pemerintahan. Sekalipun saat ini telah didekralasikan perlwanan terhadap koruptor dan tim khusu pemberantas korupsi telah dibentuk, namun prakti-praktik korupsi semakin tak terbendung dengan segala tipu muslihatnya. Oleh karena itu

74 JURNAL LISAN AL-HAL 
perlu upaya rutin dalam rangka menciptakan tata kelola pemrintahan yang baik dan menyenagkan.

Problem paling besar yang dihadapi Negara Indoesia adalah tindakan korup oleh para pejabat yang berkuasa, maka dengan segala problematika ini kita dituntut untuk terus merenung, berfikir dan melakukan terobosan-terobosan hebat, sehingga tercapailah Indonesia yang benar-benar bersih dan baik. Umtuk itu sebaiknya arah pembangunan Indonesia di arakah kepada, Pertama: pembangunan infrastruktur yang berimplikasi pada perbaikan jalan, jembatan dan sarana-sarana lain yang mendukung pada kemajuan Indonesia. Kedua: pembangunan suprastruktur, yang meliputi pada pemberantasan korupsi, pemutasan intervensi asing pada Indonesia.

Selanjutnya dari berbagai masalah yang ada harus dilakukan pemecahannya dengan beberapa pendekatan, yakni Pertama: Pendekatan secara struktur, dengan mengedepankan kesetaraan dalam berbagi tingkatan, missal dengan tidak membeda-bedakan Agama, Suku dan Rasserta lainnya yang bisa membahayakan Indonesia. Kedua: Pendekatan sosio-kultur, dalam hal ini sebaikya yang ditawarkan ke hadapan public adalah penyadaran akan nilai-nilai humanis dalam kehidupan beragama, berbangsa dan bernegara. Dengan rasa optimism dan semangat nasionalisme yang tinggi maka Indonesia akan menjadi Negara yang bermartabat karena konsep Good Governancedapat dilaksanakan dengan baik oleh lapisan bangsa Indonesia. 


\section{Daftar Pustaka}

Al Bûty, Mohammad Sâ'id Ramadhan, Fiqh al-Sîrah. Bairut: Dâr al-Fikr, 1993

al Nahrawi, Shaikh Ahmad, al Durru al Farid, dicetak bersama Fathu al Majid. Surabaya: al Hidayah, tt

Arif, Syaiful, Humanisme Gus Dur: Pergumulan Islam dan Kemanusiaan. Yogyakarta: Ar Ruzz Media, 2013

Boediardjo, Meriam, Dasar-Dasar Ilmu Politik. Jakarta: Gramedia Pustaka 2000

Busroh, Abu Daud, Ilmu Negara. Jakarta: Bumi Aksara, 2011

Echols, John M., dan Shadily, Hasan, Kamus Inggris Indonesia. Jakarta: Gramedia, 2008

el Afendi, Abdel Wahab, Masyarakat Tak Bernegara: Kritik Teori Politik Islam. Yogyakarta: LKiS:2012

Hilmy, Masdar, "Ihwal Budaya Politik Kita”, Kompas. Maret, 2014

Huda, Ni'matul, Ilmu Negara, Jakarta:Raja Grafindo Persada, 2013

Husaini, Adian, Islam Libral. Jakarta: Gema Insani: 2004

Ihsan, A. Bakir, Etika dan Logika Berpolitik. Bandung: Rosdakarya, 1999

Mahfudh, MA. Sahal, Nuansa Fiqh Sosial. Yogyakarta: LKiS, 2011

Maliki, Zainuddin, Rekonstruksi Teori Sosial Modern. Jogjakarta: Gajah Mada University Press, 2012

----------------, Sosiologi Politik, Makna Kekuasaan Dan Transformasi Politik. Yogyakarta: Gajah Mada University Press, 2010

Nurhakim, Moh., Islam, Tradisi, dan Reformasi: Pragmatisme Agama Dalam Pemikiran Hasan Hanafi. Malang: Banyumedia Publishing

Paydar, Monoucher, dalam edisi Indonesia, Legitimasi Negara Islam: Problem Otoritas Shari'ah Dan Politik Penguasa .Yogyakarta: Pajar Pustaka Baru, 2003

Permono, Sjechul Hadi, Relevansi Filsafat Hukum Nasional dan Filsafat Hukum Islam, Suatau Tinjauan Komparati”, Akademika Vol.14,No,2. Maret,2004

Rahmena, Ali, Para Perintis Zaman Baru Islam, cet. II. Bandung: Mizan, 1996

$76 \mid$ JURNAL LISAN AL-HAL 
Rais, Muhammad Dhiaudin, Al- Nazriyat al-Siyasiyat al-Islamiyah, edisi Indonesia, Teori Politik Islam. Jakarta: Gema Insani Press, 2001

Salam, Abd., Kata Pengantar buku, Aspects of The Islamic State: Religious Norms and Political, karya Monoucher Paydar, dalam edisi Indonesia, Legitimasi Negara Islam: Problem Otoritas Shari'ah Dan Politik Penguasa. Yogyakarta: Pajar Pustaka Baru, 2003

Setowara, Subhan dan Soimin, Agama dan Politik Moral. Malang: Intrans Publishing, 2013

Sjadzali, Munawir, Islam dan Tata Negara; Ajaran, Sejarah dan Pemikiran. Jakarta: UI Press, 1993

Sya'at, Ahmad, Bina Sunnah al-Muhammadiyah wa al-Shi'ah alHumainiyah. Bairut: Dar al-Fikr, 1988

Tutik, Titik Triwulan, Konstruksi Hukum Tata Negara Indonesia Pasca Amandemen UUD 1945. Jakarta:Kencana, 2011

Wahyudi, Chafid, NU \& Civil Religion; Melacak Akar Civil Riligion dalam Keagamaan NU. Yogyakarta: Graha Ilmu, 2013

Yasid, Abu, Fiqh Politik. Situbondo: Ibrahimy Press, 2009 


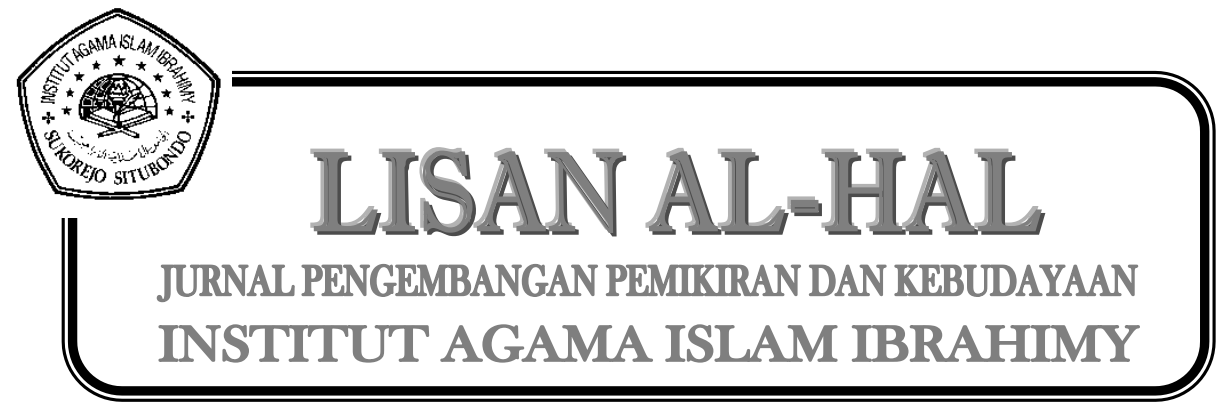

78 JURNAL LISAN AL-HAL 
